\title{
THE BUSINESS DYNAMIC OF TRADITIONAL MARKET PLACE : DEMAND PREFERENCAE APPROACH
}

\author{
R. Anang Muftiadi dan Erna Maulina \\ Department of Business Administration Science \\ Faculty of Social and Political Science, Padjadjaran University \\ Email : anang.muftiadi@unpad.ac.id \\ Email : Erna.maulina@unpad.ac.id
}

\begin{abstract}
The focus of this research is to understand the possibility of changes in the behavior of consumer demand for products in traditional markets, whether caused by internal and external factors. Traditional markets tend to focus on fresh agricultural products (perishable goods), daily and low quality durable goods, while the more modern market focus on the product packaging factory. In fact the growing type of manufacturing product, less accomodated in the traditional market. Conveniences and other factors are the important key of appeal of the traditional market. If proportion of such as consumers are greater, the the traditional market would experience faster transition into smaller markets and increasing incompetitiveness. Existence of change in traditional markets is a natural, associated with the diversification and differention of product, consumera levvel of income, technology, education, land use and changes in consumers lifestyles.
\end{abstract}

Keywords: consumer preference, agricultural products, conveniece market

\section{DINAMIKA BISNIS PADA PASAR TRADISIONAL DARI SISI PERMINTAAN KONSUMEN DENGAN PENDEKATAN DEMAN PREFERENCE}

\begin{abstract}
ABSTRAK
Fokus dari penelitian ini adalah berupaya memahami kemungkinan perubahan perilaku permintaan konsumen terhadap produk yang ada pada pasar tradisional, baik yang disebabkan oleh faktor internal maupun eksternal yang mempengaruhinya. Pasar tradisional cenderung fokus pada produk pertanian segar (perishable goods) dan sedikit barang tahan lama kualitas biasa hingga rendah, sedangkan pasar modern lebih pada produk kemasan pabrik. Secara faktual jenis produk pabrikan yang semakin berkembang, kurang terakomodasi di pasar tradisional. Kenyamanan dan ketertiban adalah kunci penting bagi daya tarik pasar tradisional. Bila proporsi yang tidak sesuai preferensinya semakin besar, maka pasar tradisional akan mengalami transisi lebih cepat menjadi pasar sub masyarakat tertentu saja dan semakin tidak kompetitif. Eksistensi pasar tradisional yang mengalami perubahan adalah hal alamiah, terkait dengan perkembangan diversifikasi dan diferensiasi produk, tingkat pendapatan, teknologi, tingkat pendidikan, perubahan tata guna lahan dan perubahan dalam pola hidup konsumen.
\end{abstract}

Kata kunci: preferensi konsumen, produk segara pertanian, kenyamanan pasar. 


\section{PENDAHULUAN}

Dinamika perubahan perilaku konsumen dan pemasaran direspon secara berbeda-beda oleh institusi pasar. Di antaranya adalah oleh keberadaan pasar tradisional, sebagai insitusi masyarakat yang pada awalnya tumbuh secara spontan dan kemudian berkembang atau bertransformasi menjadi bentuk formal. Pada akhirnya definisi pasar tradisional meluas dan bervariasi. Respon lainnya yang lebih mutakhir adalah terbentuknya pasar modern, yang secara konseptual berbeda polanya dengan pasar tradisional dalam beberapa hal. Misalnya pada pola penawaran produk pada pasar tradisional adalah tawar menawar, sedangkan pasar modern adalah harga tetap. Pola layanan pada pasar modern adalah konsumen melayani dirinya sendiri dalam memilih barang yang dibutuhkan namun di pasar tradisional dilayani langsung oleh penjualnya. Sementara pasar tradisional relatif sedikit mengalami perkembangan variansnya, justru pasar modern berkembang sangat banyak, seperti super market, department store, hypermarket sampai toko-toko kecil franchising yang dikelola secara modern. Divergensi perkembangannya semakin besar dari sisi jumlah, persebaran dan kondisinya. Perkembangan antara pasar tradisional dan modern Indonesia dapat dilihat pada tabel berikut,

Tabel 1. Perkembangan Komposisi Pasar Modern dan Tradisional di Indonesia Tahun 2000-2004

\begin{tabular}{|l|r|r|r|r|r|}
\hline $\begin{array}{c}\text { Jenis } \\
\text { Pasar }\end{array}$ & $\mathbf{2 0 0 0}$ & $\mathbf{2 0 0 1}$ & $\mathbf{2 0 0 2}$ & $\mathbf{2 0 0 3}$ & $\mathbf{2 0 0 4}$ \\
\hline $\begin{array}{l}\text { Minimar } \\
\text { ket }\end{array}$ & 3,6 & 4,7 & 5,0 & 5,4 & 7,6 \\
\hline $\begin{array}{l}\text { Superm } \\
\text { aket }\end{array}$ & 18,0 & 20,3 & 20,4 & 21,1 & 22,0 \\
\hline $\begin{array}{l}\text { Tradisio } \\
\text { nal }\end{array}$ & 78,3 & 74,9 & 74,6 & 73,4 & 70,5 \\
\hline
\end{tabular}

Sumber : A.C Nielsen (2005)

Dari tabel di atas tampak bahwa dari jumlah pasar yang ada di Indonesia, proporsi pasar tradisional berkurang sekitar 8\%, diiringi peningkatan proporsi pasar modern seperti minimarket dan supermarket. Pasar tradisional menyusut hingga $8 \%$ per tahun, sedangkan pasar modern di Indonesia tumbuh $31,4 \%$ per tahun (Kompas 2006).

Berkaitan dengan hal tersebut kemudian muncul pandangan dan persepsi masyarakat bahwa pasar tradisional kalah menarik dibandingkan pasar modern dan banyak yang lingkungannya kotor dan kumuh, sehingga dijauhi konsumen. Mudradjad (2008) menyebutkan beberapa permasalahan umum pasar tradisional seperti banyaknya pedagang yang tidak tertampung, kesan kumuh, kurang higienis pada produk makan siap saji, rendahnya kesadaran pedagang untuk mengambangkan usaha, menempati tempat yang sudah ditentukan dan membayar retribusi, status lahan, persaingan antar pasar sejenis, kontinuitas hari pasar dan lain sebagainya.

Penelitian Arianis, Tetty dan Rivani (2010) tentang keputusan pembelian konsumen pada pasar tradisional di Kota Bandung menunjukkan beberapa karakteristik perilaku konsumen yang menarik, yaitu:

Faktor interaksi sosial antara pembeli, pedagang, keluarga dan kebiasaan-kebiasaan yang dibangun dari peran sosial responden yang mayoritas adalah ibu rumah tangga menjadi faktor pendorong responden untuk memilih berbelanja di pasar tradisional. Faktor pertimbangan pribadi, seperti dalam hal menemukan harga yang lebih murah dan pengalaman yang menyenangkan ketika berbelanja di pasar tradisional bukan faktor penting yang mempengaruhi pertimbangan konsumen dalam berbelanja di pasar tradisional. Pertimbangan utama konsumen untuk memilih berbelanja di pasar tradisional adalah karena ingin harga yang murah, lokasinya dekat dari rumah, barang lebih segar dan karena sudah kenal dengan pedagangnya. Pada harga barang, meskipun responden menemukan beberapa jenis barang yang harganya lebih mahal dibandingkan tempat lain, namun adanya proses tawar menawar dapat menjadikan pasar tradisional ini tetap menarik untuk dikunjungi oleh konsumennya.

Media Ritel (2011) menyebutkan bahwa keberadaan ritel modern jelas akan sangat 
berpengaruh terhadap kelangsungan hidup ritel tradisional. Jika kondisi ritel tradisional tidak segera berbenah diri atau dengan melakukan revitalisasi, maka keberadaannya akan semakin terpinggirkan oleh hadirnya ritel-ritel modern yang secara manajemen lebih terkelola dengan baik Namun demikian, pada saat yang sama muncul pendapat dan gagasan bahwa pasar tradisional harus didukung dan diselamatkan. Salah satu upaya formal hukum adalah mengajukan retail Indomaret dan Alfamart dengan landasan UU No.5 Tahun 1999 tentang Larangan Praktek Monopoli dan Persaingan Usaha Tidak Sehat oleh Komisi Pengawas Persaingan Usaha (KPPU) dan pada akhirnya perusahaan retail tersebut dinyatakan tidak melanggar UU tersebut. Walaupun demikian gagasan dan pendapat bahwa pasar tradisional harus didukung atau dilindungi dan pasar modern perlu dikendalikan tampaknya semakin menguat. Namun demikian secara empiris perwujudannya tidak sekuat gagasannya.

Atas dasar fenomena tersebut maka penelitian ini akan dilakukan. Pemahaman yang komprehensif terhadap unsur, perilaku, keterkaitannya serta kecenderungan perubahan dalam pasar tradisional adalah informasi sangat penting bagi penyusunan kebijakan ekonomi dan publik. Kebijakan ekonomi adalah dalam kaitanya dengan substansi sektor perdagangan dan kebijakan publik berkaitan substansi kelembagaan publik dalam aktivitasnya.

Fokus dari penelitian ini adalah berupaya memahami kemungkinan perubahan perilaku permintaan konsumen terhadap produk yang ada pada pasar tradisional, baik yang disebabkan oleh faktor internal maupun eksternal yang mempengaruhinya.

Terdapat gap informasi yang mendasar pada pasar tradisional bagi penyusun kebijakan publik dan ekonomi terkait pasar tradisional. Studi pasar tradisional ini ditujukan untuk mendalami aspekaspek yang mungkin mengalami perubahan dalam perilaku konsumennya. Perubahan mungkin disebabkan oleh faktor internal dan eskternal yang secara perlahan turut membentuk pola pembelian. Tujuan dari penelitian ini adalah
[1] memperoleh deskripsi perilaku dan kecenderungan pembeli di pasar tradisional dengan mempertimbangkan aspek-aspek yang mempengaruhinya [2] memperoleh informasi strategis tentang perilaku konsumen di pasar tradisional bagi penyusunan kebijakan ekonomi, bisnis dan publik.

\section{TINJAUAN PUSTAKA}

\section{Pasar (Market)}

Pasar secara teoritis adalah suatu institusi yang bercirikan adanya kegiatan interaksi antara pembeli dan penjual yang didalamnya terdapat kesepakatan mengenai jumlah barang dan harganya. Unsur penting dalam pasar adalah adalah penawaran (supply) oleh para penjual dan permintaan (demand) oleh para pembeli. Definisi pasar menurut Mankiv (2008:65);

A market is a group of buyers and sellers of a particular good or service. The Buyers as a group determine the demand for the product, and the sellers as a group determine the supply of the product. The terms supply and demand refer to the behavior of people ... as they interact with one another in markets.

Berdasarkan pemahaman dan definisi tersebut maka sesungguhnya pasar adalah suatu konsep yang luas, yang terwujud secara fisik atau nyata dalam bentuk pasar yang berlokasi atau tetap (market place) dan pasar non fisik yang dapat bertransaksi melalui berbagai bentuk media telekomunikasi. Dengan demikian pasar tradisional dalam konteks penelitian ini, termasuk pula pasar modern, adalah dalam lingkupnya sebagai pasar berlokasi tetap (market place). Dinamika pasar (market place) dapat berkembang dan dikaitkan dengan pasar non fisik (nir lokasi), walaupun faktor keterikatannya dengan lokasi relatif masih dominan. 


\section{Pasar Sebagai Suatu Sistem}

Suatu hal yang menunjukkan adanya interaksi pada umumnya mengindikasikan pula adanya suatu sistem, baik sistem itu berskala besar maupun kecil. Dalam suatu sistem, situasi dan kondisi suatu unsur berkaitan dengan situasi dan kondisi unsur lain pada tingkatan tertentu atau perubahan yang satu akan berpengaruh pada perubahan yang lainnya. Karena itu proses pengambilan keputusan dan penentuan kebijakan memerlukan pemahaman yang komprehensif terhadap sistem tersebut, agar diperoleh tindakan atau kebijakan yang efektif, efisien dan sinergis. Secara umum, sistem didefinisikan oleh Burch dan Felix dalam Winardi (1999: 28):

System is a ubiquitous term used to describe a number of things, objects, methods, or groups. An ordered group of facts principles, philosophies, beliefs and tradition such as, the democratic system government, is described as as system.

Pendapat lain yang dikemukakan Senge (2004:10):

they are all connected within the same pattern. Each has an influence on the rest, an influence that is usually hidden from view. You can only understand the system by contemplating the whole, not any individual part of the pattern. Business and other human endeavors are also systems.

Terkait dengan pemahaman tersebut, maka penelitian tentang pasar sangat penting dilakukan dengan pendekatan sistem. Sebagai institusi yang memiliki unsur utama penawaran dan permintaan, maka pasar bercirikan sebagai suatu sistem. Secara teoritis, pasar terdiri dari empat jenis, yaitu pasar persaingan sempurna (perfect competition), persaingan monopolistik (monopolistic competition), oligopoli dan monopoli. Jenis pasar-pasar tersebut berbedabeda karena faktor karakteristik jumlah penjual dan pembeli produk, hambatan masuk atau keluar pasar, alur informasi dan tingkat keuntungannya.
Dalam penelitian pasar tradisional yang produknya berkisar antara produk homogen atau sedikit terdiferensiasi, kemudahan untuk membuat usaha atau menurut usaha, jumlah pembeli dan penjual yang relatif banyak dan ciri informasi yang lebih simetris, dapat digolongkan sebagai perpaduan antara karakteristik pasar persaingan sempurna dan persaingan monopolistik. Karena itu dalam penelitian ini karakteristik kedua jenis pasar ini akan digunakan sebagai dasar dalam menurunkan variabel-variabel penelitian.

\section{Metode Penelitian}

Metode penelitian yang digunakan dalam penelitian ini adalah metode penelitian survey. Penelitian ini berusaha menggambarkan fenomena yang terjadi pada sistem pasar tradisional berdasarkan unsur pelaku, perilaku, keterkaitan dan hubungan serta lingkungan strategisnya. Dalam penelitian ini difokuskan pada perilaku pembeli.

Karakteristik pasar tradisional yang diteliti adalah yang bercirikan pasar berkompetisi dengan pasar modern.

Karena itu ciri-ciri yang ditentukan adalah (1) beroperasi setiap hari (kontinyu) atau setiap hari seperti pasar modern, (2) tingkat substitusi produk tergolong tinggi, yaitu umumnya terletak di daerah perkotaan (3) terdapat ciri kegiatan tawar menawar secara aktif (4) belum dikelola dengan sistem manajemen modern (5) menjual barangnya secara eceran (retail). Terkait dengan karakteristik pembeli yang diteliti adalah sebagai berikut,

Tabel 2. Operasionalisasi Variabel

\begin{tabular}{|c|c|c|}
\hline VARIABEL & INDIKATOR & SKALA \\
\hline $\begin{array}{l}\text { Perilaku } \\
\text { Permintaan } \\
\text { (Demand) }\end{array}$ & $\begin{array}{ll}\text { - Segmen } \\
\text { - Dinamika perubahan }\end{array}$ & Ordinal \\
\hline $\begin{array}{l}\text { Faktor } \\
\text { karakteristik } \\
\text { Pembeli }\end{array}$ & $\begin{array}{l}\text { - Umur } \\
\text { - Pendidikan } \\
\text { - Pekerjaan } \\
\text { - } \text { Peran dalam } \\
\text { - } \text { keluarga } \\
\text { - Anggota keluarga }\end{array}$ & $\begin{array}{c}\text { Rasio - } \\
\text { Nominal }\end{array}$ \\
\hline
\end{tabular}




\begin{tabular}{|c|c|c|}
\hline VARIABEL & INDIKATOR & SKALA \\
\hline $\begin{array}{l}\text { Faktor yang } \\
\text { mempengaruhi } \\
\text { perilaku } \\
\text { pembeli } \\
\text { (eksternal) }\end{array}$ & $\begin{array}{ll}\text { - } & \text { Komoditi (termasuk } \\
\text { harga barang } \\
\text { substitusi/ }\end{array}$ & Ordinal \\
\hline
\end{tabular}

Lokasi penelitian adalah di Kota Bandung yang memiliki jumlah pasar tradisional sebanyak 18. Karena homogenitas pasar tersebut, maka penelitian dilakukan pada pasar Cihaurgeulis di Jalan PHH. Mustopha untuk mewakili daerah Bandung Utara dan Pasar Kembar di Jalan Moh. Toha untuk mewakili daerah Bandung Selatan. Pada masing-masing pasar diambil 25 orang pembeli sebagai informan.

\section{HASIL DAN PEMBAHASAN}

\section{Situasi dan Kondisi Pasar yang Diteliti}

Pasar Kembar Mas. Pasar Kembar didirikan sekitar tahun 1960-an. Berlokasi di Jl. Mohamad Toha Kota Bandung, yaitu di bagian selatan. Masyarakat sekitar mengenalnya dengan sebutan Pasar Karasak. Hingga tahun 1990 Pasar Karasak ini berganti nama menjadi Pasar Kembar Mas. Berbagai macam pedagang berjualan di Pasar Kembar ini, dari mulai sayuran, buah-buahan, daging, pakaian, hingga alat rumah tangga. Di pasar ini ada pedagang yang berjualan di dalam dan di luar pasar. Pedagang di luar pasar biasanya beroperasi mulai jam 02.00 dini hari. Jumlah pembeli yang ramai terjadi sekitar antara jam 03.00-05.00. Pedagang di sisi luar bangunan utama pasar ini mulai tutup pada jam 11.00. Untuk para penjual di bagian dalam pasar, misalnya kios daging dan sayuran, tutup antara jam 12.00-13.00, sedangkan toko kelontong tutup antara jam 13.00-16.00. Seluruh kegiatan pasar ditutup pada jam 18.00, kecuali di bagian depan pasar yang masih ada penjual aneka makanan (batagor, baso, mie ayam, dll) yang akan tutup pada jam 21.00. Secara umum pembeli dapat dikategorikan menjadi dua, yaitu pembeli yang datang sejak dini hari hingga menjelang pagi, umumnya adalah pembeli barang yang akan dijual kembali, misalnya oleh pedagang keliling atau penjualan makanan, warung dan sejenisnya. Setelah itu pembeli yang berdatangan adalah konsumen akhir rumah tangga. Area parkir di Pasar Kembar Mas tersedia cukup luas dan nyaman dan lokasinya menyatu di area pasar. Namun karena banyaknya jumlah kendaraan sepeda motor yang parkir, biasanya untuk pengunjung yang membawa kendaraan roda empat mengalami kesulitan memperoleh tempat parkir.

Walaupun ada pedagang yang berjualan di luar pasar, namun jumlah pedagang yang berjualan di dalam pasar masih lebih banyak. Posisi pedagang diatur, yaitu pada bagian paling depan diisi oleh pedagang makanan sampai yang paling belakang adalah pedagang daging. Jenisjenis pedagang yang ada di dalam Pasar Kembar antara lain, pedagang makanan jadi (batagor, baso, mie ayam dan lain sebagainya, toko kelontong, toko pakaian, toko grosir bahan pokok, sayuran, buah-buahan dan pedagang daging. Jenis pedagang yang berada di luar bangunan utama pasar umumnya adalah pedagang sayuran dan buah-buahan saja. Kioskios relatif telah diisi penuh oleh pedagang, atau hanya sedikit yang kosong.

Pasar Cihaurgeulis. Pasar Cihaurgeulis terletak di Jl. Surapati yang terletak di bagian Utara Kota Bandung, posisinya lebih dekat dengan pusat pemerintah Provinsi Jawa Barat (Gedung Sate). Selain itu Jl. Surapati adalah jalan yang menghubungkan jalan layang (fly over) menuju gerbang tol Pasteur di Kota Bandung. Pasar ini juga dikenal dengan nama Pasar Suci.

Pasar ini beroperasi sejak dini hari hingga siang hari dan setelahnya relatif sedikit pengunjung. Pada sore hari, di depan lokasi biasanya digunakan untuk berjualan makanan di tenda-tenda sementara. Sejak dini hari hingga sekitar jam 06.00, umumnya pembelinya adalah usaha warung makanan dan pedagang keliling. Setelah itu hingga siang sekitar jam 11.00 pembelinya adalah konsumen akhir rumah tangga. 
Penjual yang berada di dalam kios bangunan pasar dan di luar pasar relatif seimbang sebarannya. Penjual di luar pasar umumnya adalah pedagang sayur-mayur dan sebagian kecil menjual daging dan sandang. Pedagang yang berada di dalam pasar diantaranya menjual bumbu masakan, beras, kue-kue kering dan basah, kerupuk, ikan, pakaian, plastik, daging dan lain-lain sebagainya. Pada hari biasa, lapak (tempat dagang) yang berada di luar pasar sangat padat, namun pada pada hari minggu penjualnya hanya sedikit atau berkurang karena mereka berdagang di lokasi lain, yaitu di beberapa pasar kaget. Di dalam pasar terdapat 121 kios, 14 diantaranya tidak beraktifitas lagi. Sekitar 35 lapak beralih fungsi menjadi gudang, karena pemilik lapak lebih memilih berjualan di luar pasar. Aktivitas pembeli lebih banyak berada di luar pasar daripada di dalam pasar. Namun demikian, karena banyaknya jumlah pembeli, maka kios yang ada di dalam pasar tidak terpengaruh walaupun pada hari minggu.

Akses Pasar Cihaurgeulis termasuk sangat baik, karena berada di jalan utama yang memudahkan para pembeli untuk datang ke Pasar Cihaurgeulis ini. Selain itu kualitas jalan juga selalu bagus. Karena terletak di jalan utama dan aktivitas pasarnya tergolong tinggi, maka pasar inipun menjadi penyebab kemacetan. Umumnya terjadi pada pagi hari. Sarana parkir di Pasar Cihaurgeulis sangat tidak mencukupi bagi pengunjung atau konsumen, karena seluruh lahan parkir digunakan untuk berdagang, termasuk jalan di depan pasar. Banyak pembeli yang parkir di lapangan parkir di lokasi lain seperti di Masjid Pusdai, pompa bensin di sebelahnya dan bahkan di atas trotoar yang seharusnya untuk pejalan kaki.

\section{Profil Pembeli}

Para pembeli yang menjadi responden penelitian rata-rata berumur 38 tahun. Pembeli termuda berusia 17 tahun dan tertua 70 tahun. Sebanyak $88 \%$ responden berjenis kelamin perempuan. Responden pembeli tersebut sebagian besar adalah anggota keluarga (sebanyak 68\%), pekerja rumah tangga (16\%) dan sebagian kecil adalah kepala rumah tangga (16\%). Pada umumnya yang berbelanja di kedua pasar tersebut adalah pembeli berjenis kelamin perempuan, sehingga jarang yang berposisi sebagai kepala rumah tangga. Rata-rata jumlah anggota keluarga mereka sebanyak 4 orang. Jumlah anggota keluarga terbanyak adalah 7 orang dan tersedikit 2 orang saja. Tingkat pendidikan responden pembeli pada umumnya adalah SLTA (50\%), SD (24\%), perguruan tinggi (16\%) dan SLTP (10\%).

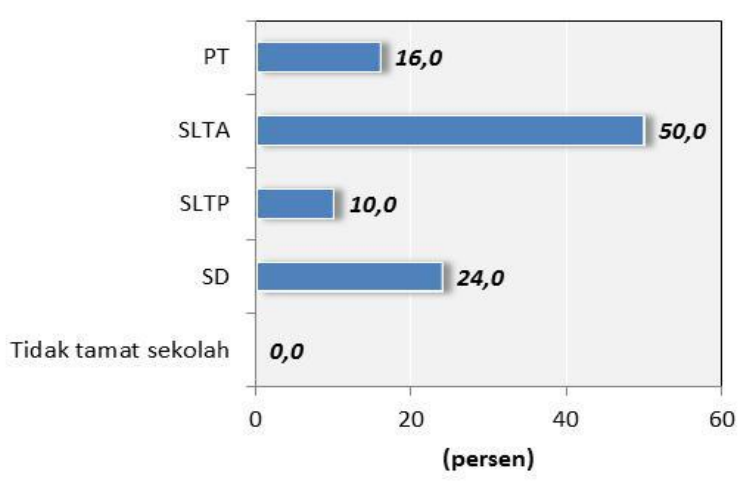

Gambar 1. Tingkat Pendidikan Responden Pembeli

\section{Kondisi Fisik dan Aksesibilitas Pasar}

Kondisi fisik pasar adalah segala sarana dan prasarana pasar yang terlihat, terasa, termasuk aromanya yang dapat ditangkap oleh indera para pembeli. Aksesibilitas pasar adalah tingkat kemudahan pencapaian pasar oleh para pembeli. Menurut hasil uji mengenai kemungkinan adanya perbedaan persepsi responden pada kondisi fisik kedua pasar tersebut, dengan menggunakan uji beda sampel independen, pembeli di Pasar Kembar Mas dan Pasar Cihaurgeulis tidak memiliki perbedaan persepsi dalam hal kondisi fisik pasar ( $p$-value $=0,075)$. Menurut persepsi responden pembeli, $70 \%$ mengatakan bahwa pasar yang diteliti, kondisi fisiknya tergolong 'biasa', 8\% yang menyatakan kondisinya 'buruk' dan $22 \%$ yang menyatakan kondisinya 'baik'. Karena sebagian besar menyatakan bahwa kondisinya fisiknya 'biasa' saja, maka sebanyak $46 \%$ merasakan 'nyaman' dan sebanyak 50\% mengatakan 'biasa saja' atau hanya $8 \%$ 
responden yang merasa 'tidak nyaman' di pasar tersebut.

Namun demikian, ini bukan berarti secara fisik kondisi pasar memang benar-benar 'baik' dan memberikan rasa 'nyaman' (lihat potret). Kemungkinan besar hal tersebut terjadi karena kebiasaan, standar dan fokus pembeli sendiri. Kebiasaan terbentuk karena mereka sering ke pasar, sehingga secara perlahan membentuk kesadaran atau penyesuaian penerimaan. Standar, diantaranya ditentukan oleh kelas sosial, pendapatan dan lain sebagainya, termasuk fleksibilitas seseorang untuk menyesuaikan standar. Kemungkinan besar pembeli terbentuk standarnya pada tingkat sekarang atau melakukan penyesuaian standar pada kondisi berbeda, sehingga tidak menetapkan standar kenyamanan tinggi pada pasar tradisional. Fokus pembeli untuk yang umumnya hanya berbelanja seharihari, pembelian pada produk tidak berstandar, hanya fokus untuk mendapatkan barang kebutuhan untuk kemudian segera pulang, dapat menyebabkan seseorang tidak acuh pada lingkungan. Faktor-faktor tersebut yang kemungkinan membuat seseorang memiliki persepsi cukup menyimpang dari kondisi sesungguhnya. Dengan percobaan menempatkan orang yang sama dalam suasana berbeda, mungkin dapat menjawab perbedaan persepsi ini.

Pada pasar-pasar yang diteliti, banyak ditemui pedagang-pedagang yang berjualan bukan ditempat yang seharusnya, seperti berjualan di bagian luar pasar, lahan parkir, pinggir jalan dan lain sebagainya. Kondisi ini sekilas tampak menguntungkan bagi pembeli dan penjualan, namun secara keseluruhan dapat mengurangi fungsi sarana lainnya dan menimbulkan dampak negatif pada pedagang di dalam pasar dan lingkungan sekitar. Kondisi ini tampaknya kurang disadari oleh penjual maupun pembeli. Orientasi berpikir yang berjangka pendek dan fokus, yaitu memperoleh kebutuhan sehari-hari di pasar dengan cepat, membuat pembeli berpikir praktis.

Dari responden yang diteliti, sebanyak $40 \%$ 'sering' melakukan pembelian pada penjual yang berada di luar pasar. Pembeli yang 'kadang- kadang' melakukannya sebanyak 34\% dan hanya $26 \%$ yang 'tidak membeli' pada penjual di luar pasar tersebut. Bila dijumlahkan pada pendapat yang mirip, maka $74 \%$ dari mereka juga membeli pada pedagang di luar pasar. Alasan mereka membeli pada pedagang di luar pasar umumnya adalah karena kemudahan atau kepraktisan. Hal ini diakui oleh $68,4 \%$ responden. Mereka membeli pada pedagang di luar pasar karena praktis, mudah dijangkau dan tidak perlu masuk ke dalam pasar lebih jauh lagi. Responden yang menyatakan lebih murah sebanyak $18,4 \%$, karena relatif lengkapnya produk $5,3 \%$ dan faktor lainnya $7,9 \%$. Pedagang-pedagang di luar pasar tersebut umumnya sah secara terbatas. Mereka sah karena mereka tetap dikenakan retribusi, disebut 'terbatas' karena sebenarnya mereka menempati tempat yang tidak semestinya atau sesuai rencana peruntukan. Perilaku pembelian yang dijelaskan di atas dapat dikatakan cukup unik, yaitu mereka membeli pada pedagang di dalam pasar dan di luar pasar, karena alasan kepraktisan dan harga yang lebih murah untuk jenis barang yang sama. Perilaku ini tampaknya terjadi sebagai respon spontan saja, bukan perilaku permanen. Artinya bila pasar ingin beroperasi secara tertib dan teratur, maka dilakukan pengaturan posisi pedagang dengan baik, maka pembeli akan cenderung mengikuti aturan tersebut. Pada para penjual tampaknya kebutuhan mereka adalah pada tempat berjualan yang sederhana, praktis dan karakteristik berjualan yang tidak kontinyu sepanjang hari dan tidak menyimpan stok besar yang berdampak pada biaya sewa tempat berjualan yang terjangkau.

Tabel 3. Preferensi Membeli di Luar Pasar

\begin{tabular}{|l|c|}
\hline \multicolumn{1}{|c|}{ ALASAN } & \% \\
\hline Mudah/praktis & 68,4 \\
\hline Lengkap & 5,3 \\
\hline Lebih murah & 18,4 \\
\hline Lainnya & 7,9 \\
\hline Total & $\mathbf{1 0 0}$ \\
\hline
\end{tabular}

Sumber : Hasil Survey 
Kesediaan pembeli berbelanja ke pasar tradisional secara teoritis ditentukan pula oleh aksesibilitasnya. Responden pembeli yang diwawancara, sebanyak $60 \%$ menyatakan bahwa mereka menuju ke pasar dengan berjalan kaki, $36 \%$ menggunakan sepeda/ sepeda motor dan $4 \%$ menggunakan kendaraan lain seperti angkutan umum atau mobil pribadi. Banyaknya responden yang berjalan kaki menunjukkan bahwa akses menuju pasar tidak terlalu jauh dari rumah atau tidak memerlukan upaya transportasi khusus. Penggunaan sepeda atau sepeda motor tidak berhubungan dengan jarak, namun terkait dengan waktu tempuh dan rasa lelah yang dialami pembeli.

Dengan asumsi rata-rata kecepatan umum orang berjalan kaki adalah $5 \mathrm{~km} / \mathrm{jam}$, maka dapat diketahui rata-rata perkiraan jarak rumah tinggal menuju ke pasar yang diteliti. Sebanyak $84 \%$ responden pergi ke pasar dengan berjalan kaki dengan waktu kurang dari 15 menit. Artinya jarak antara pasar dan rumahnya maksimum 1,25 $\mathrm{km}$. Hanya sedikit responden yang berjalan melebihi 15 menit, yaitu sekitar 18\%. Dengan demikian pada umumnya konsumen pembeli di pasar tersebut adalah penduduk yang tinggalnya tidak terlalu jauh dari pasar tersebut. Fenomena tersebut menunjukkan bahwa keberadaan pasar tradisional sangat ditunjang oleh keberadaan pemukiman di sekitarnya, bukan karena akses jalan strategis. Artinya letak pasar tidak harus berada di jalan-jalan utama, sehingga dapat menyebabkan kemacetan.

\section{Preferensi Pembeli di Pasar Tradisional}

\section{Karakteristik Pembelian}

Pembelian produk di kedua pasar yang diteliti, umumnya adalah untuk digunakan sendiri, yaitu sebanyak $84 \%$ dan hanya sedikit yang membeli untuk dijual kembali secara langsung atau diolah terlebih dahulu (16\%). Frekuensi pembelian yang dilakukan termasuk 'sangat sering', yaitu mereka berbelanja ke pasar setiap hari $(62 \%)$, seminggu sekali $(24 \%)$ dan sisanya (14\%) tidak tentu frekuensinya. Dengan intensitas tersebut, menurut persepsi mereka, sebanyak $84 \%$ responden menyatakan 'sering' ke pasar. Waktu belanja yang lakukan biasanya adalah pada pagi hari $(86 \%)$ dan hanya sedikit yang berbelanja siang hari (14\%). Pada sore hari relatif sangat sedikit lagi yang berbelanja.

Dalam keputusan mereka untuk berbelanja ke pasar tradisional tersebut, sebenarnya terbuka pilihan untuk berbelanja juga di mini market di sekitar rumah. Sebanyak $94 \%$ menyatakan ada mini market di sekitar rumah mereka, seperti Alfa Mart, Indomaret, Yomart dan lain sebagainya yang menyediakan berbagai produk kebutuhan sehari-hari juga, khususnya untuk produk kemasan dan sedikit produk peternakan seperti telur dan beberapa jenis buah-buahan tahan lama. Keberadaan mini market relatif sudah sangat mendekati konsumennya secara intensif di permukiman-permukiman. Pada jenis barang tertentu, khususnya barang-barang kemasan, terjadi kompetisi intensif antara pasar tradisional dan pasar modern seperti mini market tersebut, dengan harga yang lebih kompetitif.

\section{Produk yang Dibeli}

Produk yang dibeli responden di pasar tradisional pada umumnya adalah berupa sayurmayur, buah-buahan, serta hasil-hasil peternakan dan perikanan seperti telur, daging, ikan dan lain sebagainya. Sebanyak $90 \%$ responden membeli barang-barang jenis tersebut. Sebagian kecil lagi membeli barang-barang pabrikan atau produkproduk kemasan $(6 \%)$ dan tidak ada responden yang membeli barang-barang kebutuhan sekunder, seperti baju, peralatan rumah tangga dan lain sebagainya. Karakteristik barang-barang yang dibeli oleh konsumen di pasar tradisional secara umum memang sangat berbeda dengan produk-produk yang dibeli di pasar modern. Barang-barang yang dibeli di pasar tradisional umumnya adalah berupa barang tidak tahan lama (perishable goods), harus dibeli dalam kondisi segar dan penyimpannya memerlukan mesin pendingin. Bagi yang tidak memiliki mesin pendingin, maka pembeli harus membelinya setiap hari sesuai kebutuhannya. 
Dari produk-produk yang dibeli di pasar tradisional yang diteliti, terdapat perbedaan antara produk pertanian dan pabrikan (olahan). Menurut 64\% responden pembeli, kualitas barang hasil pertanian di pasar tradisional umumnya termasuk berkualitas 'bagus', sedangkan pada produk pabrikan hanya $36 \%$ yang mengatakan kualitasnya 'bagus'. Sebanyak 52\% responden menyatakan produk pabrikan yang ada di pasar tergolong 'biasa' kualitasnya. Bahkan ada sekitar $12 \%$ responden yang 'tidak mengetahui' kualitas produk pabrikan di pasar tersebut. Terhadap keamanan produk-produk yang dijual di pasar, sekitar 60\% menyatakan yakin 'aman', tidak yakin $18 \%$ dan yang tidak tahu $22 \%$. Terhadap kualitas produk yang dijual di kedua pasar, dilakukan uji beda sampel independen. Menurut responden pembeli di Pasar Kembar Mas dan Pasar Cihaurgeulis, yaitu tidak ada perbedaan kualitas barang hasil pertanian, yaitu keduanya umumnya sama-sama menyatakan bagus ( $p$-value $=0,5$ ). Demikian juga dengan produk pabrikan, yang menurut responden pembeli Pasar Kembar Mas dan Pasar Cihaurgeulis tidak ada perbedaan kualitas yaitu keduanya sama-sama menyatakan biasa saja ( $p$-value $=0,1148)$

Berdasarkan pengetahuan pembeli terhadap kualitas produk yang dijual di pasar tersebut, menunjukkan bahwa pembelian hasil pertanian karena mereka tahu kualitasnya relatif 'bagus'. Pada pembelian barang pabrikan, pembeli tampaknya menyadari bahwa barang-barang yang dijual 'biasa saja' kualitasnya dan bahkan ada yang 'tidak tahu' persis. Persoalan ini secara teoritis berkaitan dengan karakteristik aliran informasi antara penjual dan pembeli. Aliran informasi produk pertanian pada umumnya bersifat sysmetric artinya kedua pihak relatif lebih mengetahui kualitas produknya, sedangkan produk pabrikan, cenderung bersifat asymetric atau pembeli tidak mengetahui persis kualitas dan kondisinya. Dalam situasi ini pembeli akan cenderung membeli produk pabrikan yang lebih memberikan jaminan kualitas. Tempat yang menyediakan produk pabrikan yang lebih meyakinkan akan lebih memberikan keinginan membeli konsumen, seperti pada pada mini market atau pasar modern lainnya. Karena itulah, banyak pula responden yang membeli produk pabrikan di pasar modern seperti mini market.

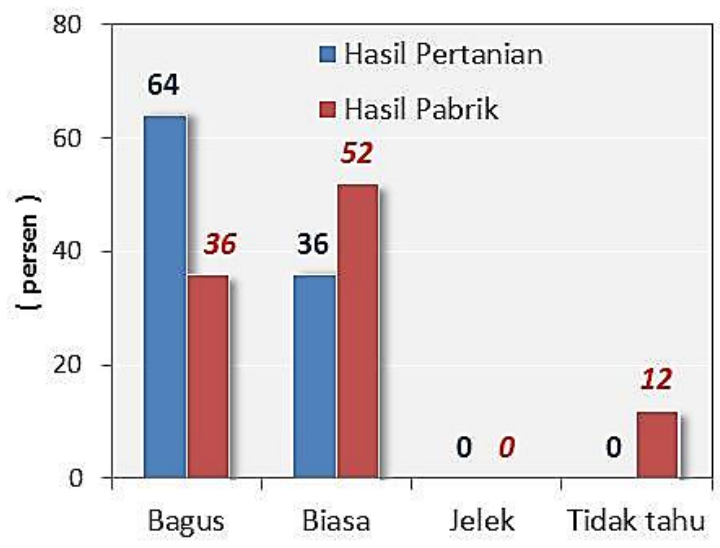

Gambar 2. Kualitas Produk di Jual

\section{Pilihan Berbelanja}

Pertimbangan terbanyak pembeli untuk memilih melakukan pembelian di pasar tradisional adalah karena pertimbangan harga yang terjangkau (price), yaitu sebanyak $70 \%$ responden. Karena faktor ketersediaan barang dijawab oleh $16 \%$ responden, karena dekat rumah sebanyak $6 \%$ responden dan sisanya atas beberapa pertimbangan seperti alasan kualitas, harus sering membeli dan karena pembelian dalam jumlah banyak. Harga produk pertanian di pasar tradisional umumnya lebih murah bila dibandingkan dengan di pasar modern. Produkproduk tersebut umumnya tidak tersedia di mini market. Karena itulah pasar tradisional tetap menjadi pilihan untuk jenis produk-produk pertanian. Pembelian produk-produk di pasar tradisional dilandasi oleh berbagai sebab, seperti tampak pada gambar berikut. 


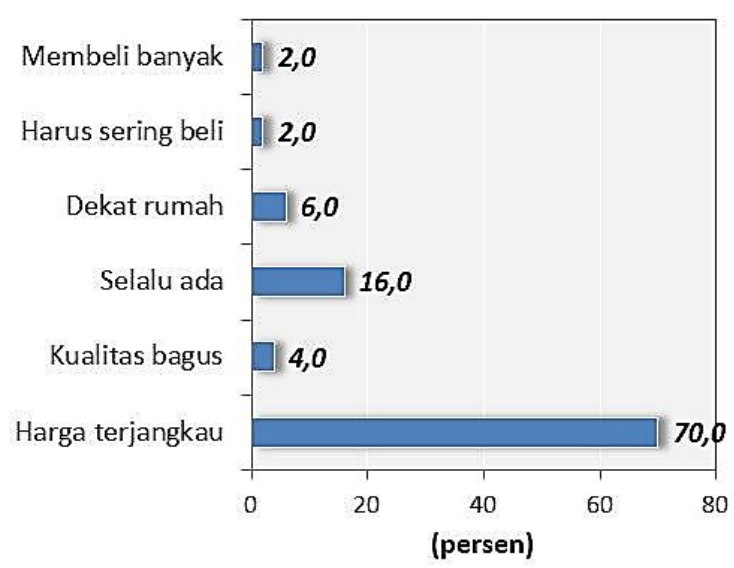

Gambar 3. Alasan Pembelian ke Pasar Tradisional

Kekhasan lain dari pasar tradisional adalah adanya tawar-menawar dalam penetapan harga produk. Pembeli pada pasar tradisional sangat memahami hal tersebut, sehingga sekitar $70 \%$ pembeli yang berbelanja ke pasar tradisional ini lebih menyukai pola tawar menawar. Proses tawar-menawar pada produk pasar tradisional dilandasi oleh karakteristik aliran informasi yang simetris yang memberikan ruang untuk membentuk keseimbangan harga dan jumlah permintaan di pasar. Hal ini kurang terjadi pada produk yang sudah terstandar seperti produkproduk pabrikan.

Pilihan berbelanja kebutuhan dengan berbelanja ke pasar rupanya menjadi, banyak tetangga responden yang juga berbelanja ke pasar tradisional. Ini dikatakan oleh $90 \%$ responden. Artinya berbelanja ke pasar masih banyak menjadi pilihan orang untuk memenuhi kebutuhan sehari-hari.

Diantara faktor yang sering diberitakan adalah kondisi fisik pasar tradisional yang kumuh. Kondisi fisik pasar biasanya dirasakan dalam bentuk kenyamanan. Berdasarkan pendapat responden tentang kondisi fisik pasar yang diteliti, responden menyatakan kondisi fisik pasar berpengaruh pada minat berbelanja di pasar tersebut. Hal ini diakui sekitar 58\% responden. Sebanyak $24 \%$ responden menyatakan bahwa kondisi fisik pasar 'cukup berpengaruh' dan hanya $18 \%$ yang menyatakan 'tidak berpengaruh' pada minat berbelanja. Berdasarkan uji beda sampel independen pada kedua pasar, menunjukkan bahwa tidak ada perbedaan antara Konsumen Pasar Kembar Mas dan Pasar Cihaurgeulis dalam hal pengaruh kondisi pasar terhadap minat belanja ( $p$-value $=0,397)$.

Jawaban ini menunjukkan bahwa pembeli memiliki preferensi tinggi terhadap kondisi fisik dan kenyamanan berbelanja di pasar tradisional. Namun karena pada kebanyakan pasar tradisional tidak tersedia kenyamanan dimaksud, maka responden dapat bertindak menurunkan standar kenyamanan, asal mendapatkan barang yang mereka butuhkan. Keadaan ini dapat menjadi pertimbangan penting bagi upaya menjadikan pasar tradisional sebagai pilihan masyarakat atau agar tidak ditinggalkan masyarakat, dengan cara meningkatkan kenyamanan.

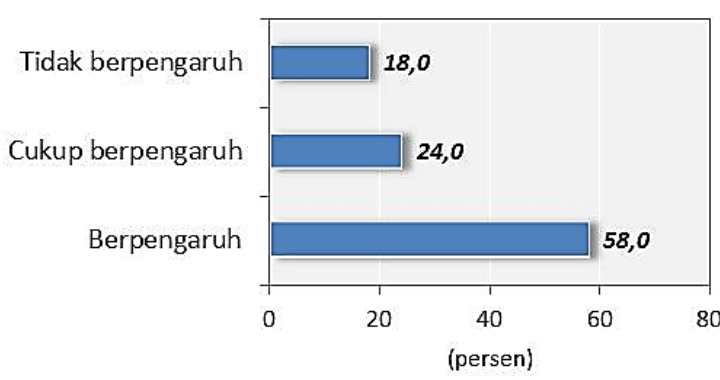

Gambar 4. Pengaruh Kondisi Fisik pada Minat Belanja

Dari hasil wawancara, kenyamanan sebenarnya menjadi keinginan pembeli. Misalnya pembeli di Pasar Cihaurgeulis, berharap memindahkan kontainer sampah di pasar yang membuat pasar terlihat sangat kumuh dan membuat pembeli meragukan tingkat kesehatan dari produk yang dijual di pasar tersebut. Pembeli cenderung membutuhkan kenyamanan seperti tersedianya lahan parkir dan keamanan, agar terhindar dari copet dan kehilangan selama berbelanja di pasar tersebut. Pedagang di pasar tersebut mempunyai preferensi penertiban lapak yang berada diluar pasar, meminta pengurus pasar untuk mengurangi dan menindak oknum yang meminta iuran/pungutan liar, transparansi pembayaran listrik dan meningkatkan keamanan di daerah pasar, terutama dari gangguan pemeras (preman). 


\section{Kompetitor}

Analisis kompetisi pasar tradisional adalah terhadap keberadaan pasar modern dan perkembangan pedagang keliling yang menggunakan sepeda motor atau gerobak.

Sering diungkapkan bahwa keberadaan pasar modern adalah sebagai faktor yang dapat mematikan pasar tradisional. Karena itu keduanya kerap menjadi topik polemik dalam berbagai diskusi. Menurut responden yang diteliti, sekitar 52\% mereka tidak berbelanja ke pasar modern atau hanya $48 \%$ yang melakukannya. Karena relatif ada mini market di sekitar tempat tinggal mereka, maka sebagian besar dari mereka, yaitu sebanyak 96\% responden juga berbelanja ke mini market di sekitar rumah. Lebih jauh dapat dilihat perbandingan jenis barang yang dibeli di pasar tradisional dan di pasar modern atau mini market. Sekitar $71 \%$ dari responden menyatakan bahwa barang yang dibeli di pasar tradisional berbeda dengan barang yang dibeli di pasar modern atau mini market. Hanya sedikit responden yang menjawab bahwa produk yang dibeli di pasar tradisional sama dengan di pasar modern $(4 \%)$ dan mini market (10\%). Namun setidaknya ada sekitar 22\% responden yang mengatakan produk yang dibeli sedikit sama.

Tampak bahwa terdapat perbedaan jenis barang yang dibeli di pasar tradisional dan pasar modern atau minimarket dan hanya sedikit yang relatif sama. Artinya produk yang dijual di pasar tradisional dengan di pasar modern atau mini market tidak bersaing (non-substitusi). Produkproduk tersebut diantaranya adalah sayur-mayur, buah-buahan, hasil peternakan dan hasil pertanian lainnya. Walaupun produk-produk tersebut di jual juga di pasar modern atau dijual terbatas di mini market, namun biasanya terdapat perbedaan harga dan standar kualitas. Walaupun demikian setidaknya tetap ada sedikit kompetisi antara pasar tradisional dengan pasar modern atau mini market, khususnya untuk produkproduk pabrikan.
Tabel 4. Kecenderungan Berbelanja Pasar Modern atau Minimarket

\begin{tabular}{|c|c|c|}
\hline & Pasar Modern & Mini Market \\
\hline Ya & 48,0 & 96,0 \\
\hline Tidak & 52,0 & 4,0 \\
\hline Total & $\mathbf{1 0 0}$ & $\mathbf{1 0 0}$ \\
\hline
\end{tabular}

Sumber: Hasil survey

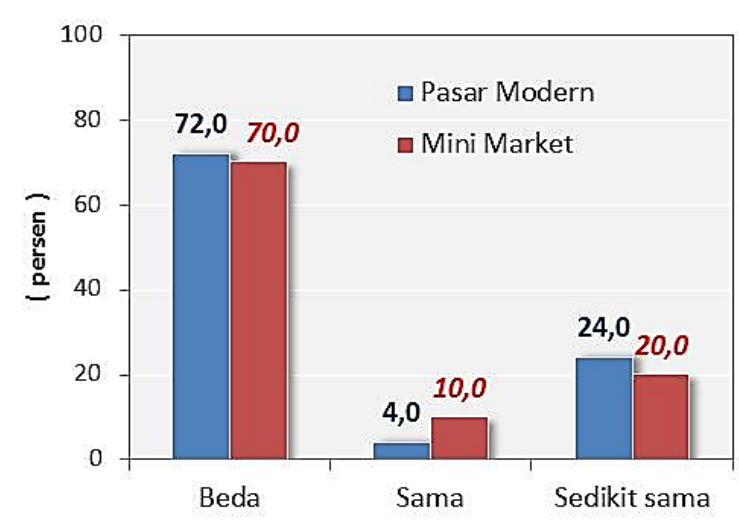

Gambar 5. Kesamaan Produk Pasar Tradisional dengan Pasar Modern dan Minimarket

Beranjak dari situasi kondisi pasar, preferensi konsumen dan kemungkinan kecenderungan perubahannya di masa yang akan datang, maka dapat digali keinginan responden untuk membeli semua kebutuhan pasar modern. Sebanyak $68 \%$ responden menyatakan tidak ingin membeli semua produk di pasar modern dan sekitar 32\% yang akan cenderung membeli semua di pasar modern, atau hampir sepertiga responden berkeinginan demikian. Berdasarkan pendapat ini, maka keberadaan pasar tradisional sebenarnya masih menjadi pilihan pembeli.

Faktor penarik responden untuk berbelanja di pasar modern atau mini market terutama disebabkan oleh tingkat kenyamanan (50\%), kelengkapan produk yang akan dibeli $(37,5 \%)$, harga $(6,3 \%)$ dan faktor lainnya. 


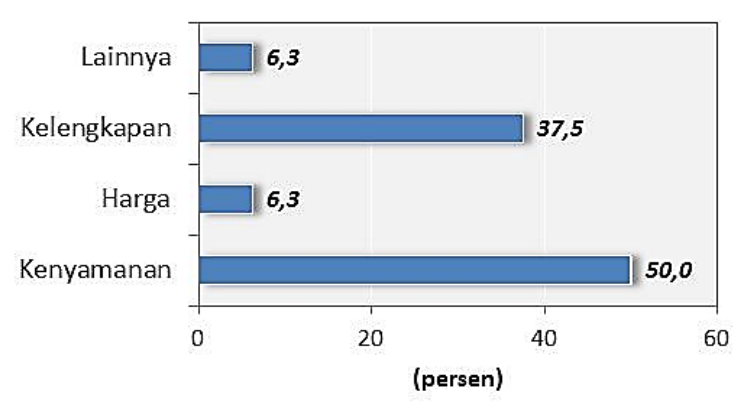

Gambar 6. Faktor Penarik Pasar Modern

Dalam hal kompetitor pedagang keliling, pada masa sekarang ini, orang dapat memenuhi kebutuhan sayur mayur dan sejenisnya dari penjual keliling, sehingga tidak perlu pergi berbelanja ke pasar. Pada pembelian sedikit atau harian, banyak rumah tangga yang cenderung lebih suka membeli dari pedagang keliling. Karena pedagang keliling umumnya membeli barang-barang dari pasar, maka harga jualnya biasanya lebih tinggi daripada harga pasar, sebagai bentuk keuntungan dan pengganti biaya transportasi. Keberadaan penjual keliling pada dasarnya merupakan kompetitor para pedagang di pasar tradisional, bila pembeli enggan membeli langsung ke pasar.

Berdasarkan survey pada responden, diperoleh informasi bahwa diantara mereka yang tidak membeli ke pedagang keliling sebanyak $42 \%$. Responden yang membeli pada pedagang keliling juga selain membeli di pasar tradisional sebanyak $46 \%$, sedangkan $12 \%$ kadang-kadang membeli dari pedagang keliling. Bila jumlah yang membeli dan yang kadang membeli pada pedagang keliling adalah sebanyak 58\%, maka relatif banyak juga responden yang membeli kebutuhan dari pasar tradisional maupun dari pedagang keliling. Pembelian pada pedagang keliling kadang-kadang adalah untuk melengkapi beberapa kekurangan yang belum atau lupa dibeli di pasar tradisional. Tampaknya pedagang keliling lebih berperan sebagai komplementer dalam penyediaan produk, jadi bukan sebagai kompetitor. Lebih jauh bila ditanyakan kepada pembeli, walaupun bila ada pedagang sayur keliling yang lengkap, sebanyak $76 \%$ responden masih tetap bersedia membeli dari pasar tradisional, sedangkan $24 \%$ menyatakan tidak akan ke pasar lagi, karena sudah ada penyedia barang pengganti.

\section{SIMPULAN}

1. Perilaku dan kecenderungan pembeli di pasar tradisional dan aspek aspek yang mempengaruhinya.

a. Pembeli umumnya perempuan dan berstatus sebagai anggota keluarga dengan tingkat pendidikan bervariasi dari tinggi hingga rendah. Hal ini sebagai representasi pasar tradisional di akses oleh berbagai kalangan.

b. Konsumen berbelanja untuk keperluan sehari-hari pada produk tidak berstandar seperti sayur mayur, buah-buahan, bahan pokok dan hasil perikanan dan peternakan. Produknya tergolong sebagai produk tidak tahan lama (non perishable goods). Sedikit yang membeli produk kemasan pabrikan. Orientasi berbelanja berjangka pendek, yaitu segera mendapat barang-barangnya dan segera pulang kembali.

c. Lokasi pasar umumnya tidak terlalu jauh dari rumah atau tidak memerlukan upaya transportasi khusus, sekitar $60 \%$ berjalan kaki, $36 \%$ berkendara roda dua.

d. Pertimbangan terbanyak pembeli untuk memilih melakukan pembelian di pasar tradisional adalah karena pertimbangan harga yang terjangkau dan tidak tersedia di mini market.

e. Tawar menawar lebih disukai, yang dilandasi informasi simetris atas produknya. Hal ini sedikit terjadi pada produk kemasan pabrik.

f. Kondisi fisik pasar termasuk buruk, tidak teratur, kotor, walaupun menurut persepsi responden adalah termasuk 'biasa'. Banyak juga pedagang yang tidak berdagang di tempat semestinya, seperti di luar area pasar, lahan parkir dan lainlain. Konsumen pada akhirnya banyak juga yang membeli pada pedagang di luar. 
g. Kondisi fisik pasar berpengaruh pada minat beli. Pembeli memiliki preferensi tinggi terhadap kondisi fisik dan kenyamanan berbelanja di pasar tradisional. Namun karena pasar tradisional tidak tersedia kenyamanan dimaksud, maka responden bertindak menurunkan standar kenyamanan, asal mendapatkan barang yang mereka butuhkan. Karena pasar tradisional banyak yang tidak nyaman, maka responden bertindak menurunkan standar kenyamanan, asal mendapatkan barang yang mereka butuhkan. Keadaan ini dapat menjadi pertimbangan penting bagi upaya menjadikan pasar tradisional tidak ditinggalkan masyarakat, dengan cara meningkatkan kenyamanan.

h. Pada dasarnya terbuka peluang pilihan bagi pembeli untuk berbelanja ke mini market di sekitar rumah (94\%). Sebanyak 96\% responden juga berbelanja ke mini market di sekitar rumah. Sekitar 52\% mereka tidak berbelanja ke pasar modern.

i. Terdapat perbedaan jenis barang yang dibeli di pasar tradisional dan pasar modern atau minimarket. Sekitar $71 \%$ responden menyatakan bahwa barang yang dibeli di pasar tradisional berbeda dengan barang yang dibeli di pasar modern atau mini market. Artinya produk yang dijual di pasar tradisional dengan di pasar modern atau mini market relatif tidak bersaing terlalu kuat (nonsubstitusi). Pada produk kemasan terstandar, telah terjadi kompetisi kuat antara pasar tradisional dan modern.

j. Sebanyak $68 \%$ responden menyatakan tidak ingin membeli semua produk di pasar modern dan sekitar 32\% yang akan cenderung membeli semua di pasar modern. Keberadaan pasar tradisional masih menjadi pilihan pembeli untuk jenis produk tertentu. Faktor penarik responden untuk berbelanja di pasar modern atau mini market terutama disebabkan oleh tingkat kenyamanan
(50\%), kelengkapan produk yang akan dibeli $(37,5 \%)$, harga $(6,3 \%)$ dan faktor lainnya.

k. Pedagang keliling bukan termasuk kompetitor besar pasar tradisional. Responden yang tidak membeli ke pedagang keliling sebanyak $42 \%$. Responden yang membeli pada pedagang keliling juga selain membeli di pasar tradisional sebanyak $46 \%$, sedangkan $12 \%$ kadang-kadang membeli dari pedagang keliling

1. Kecenderungan perubahan pola berbelanja karena teknologi SMS sementara waktu belum efektif. Sebanyak $52 \%$ menyatakan tidak bersedia berbelanja melalui SMS karena praktis. Yang tidak mau 48\% karena kuatir beda kualitas.

2. Informasi strategis tentang perilaku konsumen di pasar tradisional bagi penyusunan kebijakan ekonomi, bisnis dan publik.

a. Eksistensi pasar tradisional yang mengalami perubahan adalah hal alamiah, terkait dengan perkembangan diversifikasi dan diferensiasi produk, tingkat pendapatan, teknologi, tingkat pendidikan, perubahan tata guna lahan dan perubahan dalam pola hidup konsumen.

b. Bila dahulu banyak kebutuhan diperoleh dari pasar tradisional, namun pada masa sekarang keduanya cenderung terdiferensiasi. Pasar tradisional cenderung fokus pada produk pertanian segar (perishable goods) dan sedikit barang tahan lama kualitas biasa hingga rendah, sedangkan pasar modern lebih pada produk kemasan pabrik. Secara faktual jenis produk pabrikan yang semakin berkembang, kurang terakomodasi di pasar tradisional.

c. Kenyamanan dan ketertiban adalah kunci penting bagi daya tarik pasar tradisional. Konsumen akan cenderung mengikuti 
pola yang berkembang di pasar tersebut. Bila tidak sesuai dengan preferensinya, maka konsumen beralih ke pasar yang lebih memberikan kenyamanan. Bila proporsi yang tidak sesuai preferensinya semakin besar, maka pasar tradisional akan mengalami transisi lebih cepat menjadi pasar sub masyarakat tertentu saja dan semakin tidak kompetitif.

\section{DAFTAR PUSTAKA}

A.C. Nielsen (2005), Asia Pacific Retail and Shopper Trends 2005 [Tren Pembeli dan Ritel Asia Pasifik 2005]. [online] <http://www.acnielsen.de/pubs/documents/R etail and Shopper Trends Asia2005.pdf>

Arianis, Chan., Tetty Herawati dan Rivani (2010), Analisis Faktor-Faktor yang Mempengaruhi Perilaku Konsumen dalam Keputusan Berbelanja di Pasar Tradisional, Penelitian Muda FISIP Unpad.

Hall, Robert E and Lieberman, Marc (2009), Economics: Principles and Applications, second edition, ebook.

Husein Umar (2005), Riset Pemasaran dan Perilaku Konsumen, Gramedia, Jakarta.

Kompas (2006), Jangan Biarkan Pasar Bersaing dengan Hipermarket' [online] http://www.kompas.com/kompascetak/0606/ 02/metro/ 2693747.htm> [2 Juni 2006]

Mankiw, N. Gregory (2008), Principles of Micro Economics, fifth edition, South Western

McKenzie, Richard $\mathrm{B}$, and Lee, Dwight $\mathrm{R}$ (2008), Microeconomics for MBAs: The Economic Way of Thinking for Managers

\footnotetext{
Mudradjad Kuncoro (2008), Strategi Pengembangan Pasar Modern dan Tradisional Modern Tradisional, Makalah Kadin Indonesia
}

Senge, Peter M. (2004), The Fifth Discipline: The Art and Practice of Learning Organization

Winardi (1999), Pengantar Tentang Teori Sistem dan Analisis Sistem, Penerbit CV. Mandar Maju. 